\title{
Molecular cloning and characterization of an invertebrate homologue of a neuropeptide $Y$ receptor
}

\author{
Cornelis P. Tensen, ${ }^{1,2, *}$ Kingsley J. A. Cox ${ }^{3, \dagger}$ Julian F. Burke, ${ }^{3}$ Rob Leurs, ${ }^{4}$ Roel C. van der Schors, ${ }^{2}$ \\ Wijnand P. M. Geraerts, ${ }^{2}$ Erno Vreugdenhil ${ }^{1, \neq}$ and Harm van Heerikhuizen ${ }^{1}$ \\ ${ }^{1}$ Department of Biochemistry and Molecular Biology, Graduate School of Neurosciences, Research Institute Neurosciences, \\ De Boelelaan 1083, NL-1081 HV Amsterdam, the Netherlands \\ 2Department of Molecular Neurobiology, Graduate School of Neurosciences, Research Institute Neurosciences, De Boelelaan \\ 1087, NL-1081 HV Amsterdam, the Netherlands \\ ${ }^{3}$ Biochemistry Laboratory, School of Biological Sciences, University of Sussex, Falmer, Brighton BN1 9QG, UK \\ ${ }^{4}$ Department of Pharmacochemistry, Leiden/Amsterdam Center for Drug Research, De Boelelaan 1083, NL-1081 HV \\ Amsterdam, the Netherlands
}

Keywords: G-protein-coupled receptor, ligand screening, Lymnaea stagnalis, neuropeptide receptor

\begin{abstract}
Neuropeptide $Y$ is an abundant and physiologically important peptide in vertebrates having effects on food intake, sexual behaviour, blood pressure and circadian rhythms. Neuropeptide $Y$ homologues have been found in invertebrates, where they are very likely to play similar, important roles. Although five neuropeptide Y-receptor subtypes have been identified in mammals, none has been reported from invertebrates. Here we describe the cloning of a neuropeptide Y-receptor from the brain of the snail Lymnaea stagnalis. The identity of the receptor was deduced by expressing the neuropeptide Y-receptor-encoding cDNA in Chinese Hamster Ovary cells, which were subsequently challenged with size-fractionated Lymnaea brain extracts. An active peptide, selected on the basis of its ability to induce changes in cAMP levels, was purified to homogeneity, analysed by mass spectrometry and amino acid sequence determination, and turned out to be a Lymnaea homologue of neuropeptide $\mathrm{Y}$.
\end{abstract}

\section{Introduction}

Neuropeptides in vertebrates and invertebrates play key roles as signalling molecules in the regulation of physiology, behaviour and development. Their receptors generally belong to the class of Gprotein-coupled receptors (GPCRs), a superfamily of proteins characterized by a remarkable degree of functional and structural similarity (Probst et al., 1992) The vertebrate neuropeptide Y family of peptides includes neuropeptide Y (NPY), which is expressed in the central and peripheral nervous system, peptide YY (PYY) and pancreatic polypeptide (PP), which are gut endocrine peptides (see Larhammar, 1996a for review). These peptides display a wide array of biological activities that are thought to be mediated through pharmacologically distinct GPCRs. To date, five members of the human NPY receptor family have been cloned (see Larhammar, 1996b; Blomqvist \& Herzog, 1997 for a review). Of these, three (designated Y1, Y2 and Y5) have similar affinities for NPY and PYY (Herzog et al., 1992; Larhammar et al., 1992; Gerald et al., 1995; Rose et al., 1995; Gehlert et al., 1996; Gerald et al., 1996), the fourth (Y4) is selective for PP (Bard et al., 1995; Lundell et al., 1995). In addition, a sequence encoding a fifth, nonfunctional member (designated y6) has been reported (Gregor et al.,1996; Matsumoto et al., 1996).

In the mollusk Lymnaea stagnalis, a number of individual neurons have been identified with defined functions, e.g. control of heart rate, egg laying or feeding behaviour (Geraerts et al., 1991). These neurons provide excellent model systems to unravel basic aspects of neuropeptidergic transmission. Recently, we cloned several cDNAs encoding G-protein $\alpha$ subunits and one $\beta$ subunit from the central nervous system (CNS) of Lymnaea (Knol et al., 1992; Knol et al., 1994; Knol et al., 1995a, 1995b). The deduced proteins are highly homologous to their mammalian counterparts, suggesting that the molecular mechanisms underlying G-protein-mediated signal transduction in these invertebrate neurons are similar to mechanisms operative in the mammalian brain.

Correspondence: H. van Heerikhuizen, as above. E-mail: vheerik@chem.uu.nl

*Present address: Department of Dermatology, Amsterdam Leiden Institute for Immunology, De Boelelaan 1117, NL-1081 HV Amsterdam, the Netherlands

$\dagger$ Present address: Department of Neurobiology and Behaviour, State University of New York at Stony Brooke, Stony Brooke, NY 11794 5230, USA

$\ddagger$ Present address: Department of Medical Pharmacology, Leiden/Amsterdam Center for Drug Research, Sylvius Laboratories, PO Box 9503, NL-2300 RA Leiden, the Netherlands 
As a further step towards the identification of proteins involved in G-protein-mediated signal transduction pathways in Lymnaea, we isolated cDNAs encoding neuronal GPCRs using PCR amplification of cDNA synthesized from mRNA isolated from Lymnaea brains, in combination with sets of degenerate oligonucleotides corresponding to conserved domains of identified vertebrate neuropeptide receptors. This resulted in the isolation of several cDNAs encoding putative neuropeptide receptors. Initial results showed that the addition of a crude peptide extract isolated from Lymnaea brains reduced forskolinstimulated cAMP levels when added to CHO cells transfected with the Lymnaea 'orphan' receptor GRL105. This assay was then used to purify the ligand to homogeneity. Protein sequence and mass spectroscopic analysis showed that the peptide had considerable homology to vertebrate NPYs. We therefore conclude that GRL105 represents the first NPY-receptor isolated from an invertebrate.

\section{Materials and methods}

\section{Animals}

Adult Lymnaea stagnalis (shell height $28-34 \mathrm{~mm}$ ) were bred in the laboratory under standard conditions.

\section{Molecular procedures}

Standard procedures were performed as described by Sambrook et al. (1989). Restriction enzymes were purchased from Boehringer Mannheim (Almere, the Netherlands).

\section{Isolation of CDNA clones}

Total RNA isolated from Lymnaea CNSs was converted into first strand cDNA using oligo(dT) and reverse transcriptase, as described previously (Tensen et al., 1994). Two primers corresponding to DNA sequences within TMIII and TMVI of GPCRs (Libert et al., 1989; Probst et al., 1992), sense: 5' CCGGATCCG(CT)(GC)AT(CT)(GA)(GC)GC)IT(GT)GAC(CA)G(GC)TA-3'; antisense 5'-ACGAATTCGG(GC)(CA)ICCA(GA)CAGAI(GC)(GA)(CT)(GA)AA3'; with $\mathrm{I}=$ Inosine), were used in a PCR following conditions described earlier (Tensen et al., 1994). Multiple PCR products were generated, and those of the expected size (400-800 bps) were isolated, cloned and sequenced as described (Tensen et al., 1994). Oligonucleotides based on one of the obtained sequences were used to screen and isolate the corresponding full length cDNA clone from a $\lambda \mathrm{ZAP}$ II Lymnaea CNS cDNA library. The cDNA insert from this $\lambda$ clone was in vivo excised as a pBluescript SK-phagemid (pBS-GRL105) and sequenced on both strands using the dideoxy chain termination method (Sanger et al., 1977) with denatured double stranded DNA as a template, using the Sequenase DNA sequencing kit (United States Biochemicals, Cleveland, OH, USA). Automated sequencing was also performed with an ABI 373 automated DNA sequencer (Applied Biosystems, Foster City, CA, USA).

\section{Expression of GRL105 and second messenger assays}

The complete open reading frame of pBS-GRL105 was amplified by PCR (25 cycles) using $100 \mathrm{ng}$ of pBS-GRL105, a thermostable enzyme with proof-reading activity (Pfu, Stratagene, La Jolla, CA, USA), and two primers based on the cDNA sequence. Sense: $5^{\prime}$ CCGACCTAAGCTTCCGCCATGGCCGTTCTGCTCGAGCA-3' [corresponding to a region comprising the start codon with the nucleotides surrounding the start ATG (underlined) modified to an optimal consensus sequence for translation initiation (Kozak, 1987)]. Antisense: 5'-GGCTCTAGACCCACGTCAAGAGAACTC-
GTCCATCA-3' (corresponding to a region localized 200 nts downstream of the predicted stop codon). The resulting cDNA (containing a HindIII restriction site at the $5^{\prime}$ end and a $\mathrm{XbaI}$ restriction site at the $3^{\prime}$ end, as engineered in the PCR primers) was digested with HindIII and XbaI, and cloned into the HindIII and XbaI sites of plasmid pcDNA I/neo (Invitrogen, San Diego, CA, USA). After sequence confirmation, this plasmid was transfected into $\mathrm{CHO}-\mathrm{K} 1$ cells (ATCC CCL 61) using lipofectin following the manufacturers instructions (Life Technologies, Gaithersburg, MD, USA). Stably transfected cells were selected by continuous selection with the neomycin analogue $\mathrm{G} 418(400 \mu \mathrm{g} / \mathrm{mL})$ in DMEM supplemented with $10 \%$ foetal calf serum and $1 \%$ glutamine.

cAMP was assayed in whole cells $\left(2 \times 10^{5}\right.$ cells $/ 0.2 \mathrm{~mL}$ reaction volume) and quantified as described by Leurs et al. (1994). Intracellular calcium was assayed as described previously (Cox et al., 1997) and quantified using equations described by Grynkiewicz et al. (1985).

\section{Extraction and HPLC purification}

Lymnaea CNSs were dissected, collected on dry ice and stored at $-60{ }^{\circ} \mathrm{C}$ until use. CNSs were rapidly thawed at room temperature, sonicated in $1 \mathrm{M}$ acetic acid over ice, centrifuged at $10000 \mathrm{~g}$ for $5 \mathrm{~min}$ and the resulting supernatant was applied to a C18 solid phase extraction column (Supelclean, Supelco, Bellefonte, PA, USA). Bound material was eluted with $60 \% \mathrm{CH}_{3} \mathrm{CN}$ and $7 \mathrm{~mm}$ trifluoroacetic acid (TFA), and directly analysed by high-performance gel permeation chromatography (HPGPC) by application to Protein-Pak columns I-125 and I-300 connected in series (Waters Associates, Milford, CA, USA). The running buffer was $7 \mathrm{~mm}$ TFA in $30 \% \mathrm{CH}_{3} \mathrm{CN}$. Obtained fractions were lyophilized, redissolved in distilled water and aliquots were tested in the bioassays. The combined fractions 18-20, obtained after HPGPC, were subjected to reversed phase HPLC (rpHPLC). First a Nucleosil C18 column (Maherey-Nagel, Germany; $250 \times 4.6 \mathrm{~mm}$ ) was used, applying a discontinuous linear gradient of water and $\mathrm{CH}_{3} \mathrm{CN}$ in $7.5 \mathrm{~mm}$ TFA $\left(10 \mathrm{~min} 0 \% \mathrm{CH}_{3} \mathrm{CN}\right.$, then from 0 to $60 \% \mathrm{CH}_{3} \mathrm{CN}$ over $60 \mathrm{~min}$ ). After lyophilization, bioactive fractions were rechromatographed on a similar column (Nucleosil $\mathrm{C} 18 ; 250 \times 2.1 \mathrm{~mm})$ applying a discontinuous linear gradient of water and $\mathrm{CH}_{3} \mathrm{CN}$ in $0.05 \% \mathrm{HCl}\left(10 \mathrm{~min} 0 \% \mathrm{CH}_{3} \mathrm{CN}\right.$, then from 0 to $60 \% \mathrm{CH}_{3} \mathrm{CN}$ over $60 \mathrm{~min}$ ). In the last run, lyophilized bioactive fractions were rechromatographed using the same column and elution system, but using a more shallow gradient (in 10 min to $12 \% \mathrm{CH}_{3} \mathrm{CN}$, then from 12 to $24 \% \mathrm{CH}_{3} \mathrm{CN}$ over $40 \mathrm{~min}$ ).

\section{Amino acid sequence determination}

Amino acid sequences were determined with a pulse liquid automatic sequencer (Applied Biosystems, Foster City, CA, USA, model 477) and an on-line rpHPLC system (Applied Biosystems, Foster City, CA, USA, model 120A) to detect phenylthiohydantoin amino acids using sequencing programs recommended by the manufacturer.

\section{Peptide synthesis}

LyNPY and lyNPY analogues were synthesized on an Applied Biosystems (Foster City, CA, USA, model 432A) peptide synthesizer by FMOC and $\mathrm{HBOC}$ chemistry, following procedures recommended by the manufacturer.

\section{Mass determination}

The precise molecular masses of peptides were obtained using a Quattro-BQ triple quadrupole mass spectrometer (Micromass, UK). 
The mass spectrometer was equipped with an electrospray atmospheric pressure ionization source. The peptide was dissolved in $20 \mu \mathrm{L}$ of $50: 50$ acetonitril/water plus $1 \%$ formic acid, and the resulting solution was injected via a $10 \mu \mathrm{L}$ loop into the electrospray source. The flow rate was $4 \mu \mathrm{L}$ per min and the mobile phase was 50:50 acetonitril/water plus $1 \%$ formic acid. Data were acquired over a suitable mass range and several $10 \mathrm{~s}$ continuum scans were accumulated.

\section{Results}

\section{Isolation of cDNAs encoding neuropeptide receptors in the brain of Lymnaea stagnalis}

A combination of two degenerate oligonucleotide primers corresponding to amino acid sequence motifs conserved in TMIII and TMVI of many GPCRs was used to perform PCR reactions on Lymnaea stagnalis CNS cDNA. Sequence analysis of cloned PCR products showed that at least three of the fragments were derived from cDNA sequences encoding different GPCRs. Based on the sequence of one of these clones, a specific oligonucleotide was synthesized which was used in a PCR-based screening of a Lymnaea CNS-specific $\lambda$ ZAP II cDNA library (Tensen et al., 1994) in order to isolate an individual $\lambda$ clone encoding the full-length cDNA sequence. Sequence analysis of this clone revealed a cDNA insert of $3.0 \mathrm{~kb}$ containing an open reading frame of $1008 \mathrm{bp}$. This sequence has been deposited in the GenBank database under accession number X82088. We propose that translation initiation takes place at the ATG at position 776-778, because the sequence context of this ATG is in good agreement with the consensus sequence for eukaryotic translation initiation sites (CCA/GCCATGG; Kozak, 1987) and stops are found in all three reading frames preceding this ATG. Conceptual translation of the open reading frame following the proposed initiation codon predicts a protein of 336 amino acids (designated GRL105; see Fig. 1), which shows defining characteristics of GPCRs. These include seven hydrophobic, putative transmembrane-spanning domains, as well as amino acid residues highly conserved among GPCRs. A search of the GenBank (Pearson \& Lipman, 1988) showed that this putative GPCR has the highest homology to mammalian NPY receptors (Herzog et al., 1992; Krause etal., 1992; Larhammar et al., 1992; Gerald et al., 1995; Rose et al., 1995; Gerald et al., 1996; see Fig. 1).

\section{Identification of the endogenous ligand for neuropeptide receptor GRL105}

Although the Lymnaea receptor shows significant homology to vertebrate NPY-receptors (e.g. $28.1 \%$ to Y1, $31.1 \%$ to Y2, $28.0 \%$ to $\mathrm{Y} 4,28.5 \%$ to $\mathrm{Y} 5$ and $31.5 \%$ to $\mathrm{y} 6$ when comparing the transmembrane regions and interconnnecting sequences), this itself is not sufficient to propose a priori that GRL105 is indeed a Lymnaea homologue of a vertebrate NPY-receptor. To identify the endogenous ligand for this putative Lymnaea NPY-receptor, the complete open reading frame of the GRL105 cDNA was cloned into a mammalian cell expression vector (pcDNA I/neo) and then stably transfected into CHO-K1 cells. Several clones were selected for further experiments. We used a biological characteristic of GPCRs, modulation of second messenger levels at the cytoplasmic face of the plasma membrane upon binding of a specific extracellular signalling molecule, as a bioassay for the identification of the endogenous ligand for GRL105. Because the receptor is expressed in the CNS, we presumed that its endogenous ligand(s) would also be present there. Therefore, the neuropeptide content of 550 snail brains was purified using HPGPC (Fig. 2A1). Subsequently, these HPGPC fractions were tested for their ability to alter cyclic AMP (cAMP) levels in 10 stably transfected cell lines. None of the HPGPC fractions was able to stimulate an increase in cAMP levels directly. However, the pooled fractions 17-21 reduced forskolin-stimulated increase in cAMP levels to almost basal levels (Fig. 2A2) in one of the 10 cell lines tested (designated 105KCHO6). When these fractions were tested separately on 105KCHO6, the ability to reduce forskolin-stimulated cAMP levels was found to reside in fractions 18-20 (Fig. 2A3). Active material was further purified using three rounds of reversed phase HPLC (Fig. 2B-D), applying the inhibition of forskolin-stimulated cAMP increase in $105 \mathrm{KCHO} 6$ as a bioassay. By the use of mass spectroscopy, it was shown that both positive fractions from the final HPLC run (see Fig. 2D) contained a single peptide with either a $M_{\mathrm{w}}$ of $4249 \mathrm{Da}$ (fraction 39) or $4681 \mathrm{Da}$ (fraction 41). Partial protein sequencing revealed that the two peptides were identical, except for the four N-terminal amino acids that were absent in the $4249 \mathrm{Da}$ peptide. Since the mass difference between both peptides was accounted for by the observed difference of four amino acids, we assume that the peptide in fraction 39 is an N-terminally truncated form of the fraction 41 peptide. For complete sequence analysis of this latter peptide, a further 500 Lymnaea brains were successfully processed in a similar way, thus generating the sequence of 38 amino acid residues. The calculated mass of these residues is $4535 \mathrm{Da}$, thus leaving a mass difference of $146 \mathrm{Da}$ between the mass of the peptide in fraction 41 and the mass of the first 38 residues. As the mass of an amidated phenylalanine is precisely $146 \mathrm{Da}$, this is a strong indication that the fraction 41 peptide ends in a Phe residue. To really prove this assumption, we have cloned the cDNA encoding the precursor of the pertinent peptide (Tensen et al., unpublished). The sequence predicted from this cDNA is fully consistent with our protein sequencing data, but continues at position 39, with a Phe followed by the sequence Gly-Lys-Arg being the common signal for processing and subsequent amidation (Bradbury \& Smyth, 1991). The peptide sequence thus obtained has a clear homology to vertebrate, as well as invertebrate NPYs (Fig. 3), and therefore is designated Lymnaea NPY (lyNPY).

These data strongly suggest that lyNPY is the ligand for the receptor GRL105. To confirm this, lyNPY was synthesized chemically and tested for its ability to reduce forskolin-stimulated cAMP levels in 105KCHO6. Indeed, synthetic lyNPY showed potent activity (see dose-effect curve in Fig. $4 \mathrm{~A}$ ), with an $\mathrm{EC}_{50}$ of $6.0 \pm 1.5 \times 10^{-10} \mathrm{M}$, confirming the identity of lyNPY as natural ligand for the putative NPY receptor GRL105. No effect on cAMP accumulation was found in untransfected control cell lines (not shown). We also examined the effects of lyNPY on intracellular $\mathrm{Ca}^{2+}$ levels. In Fig. 4B, we show that stimulation of $105 \mathrm{KCHO} 6$ cells with lyNPY results in an increase in intracellular calcium. This dose-dependent rise in intracellular calcium is maximal at $10 \mathrm{nM}$ lyNPY. Experiments with synthetic lyNPY analogues consisting of residues 3-39 and 10-39 showed that the 3-39 form can elicit a $\mathrm{Ca}^{2+}$ response in GRL105-transfected CHO cells, although a much higher concentration $\left(10^{-6} \mathrm{M}\right)$ is required for a maximal response. The 10-39 form has only a minimal effect at a concentration of $10^{-6} \mathrm{M}$, while lower concentrations were completely inactive. Several other peptides (human NPY, human PP, VIP, FMRFamide, CCK, substance P, substance K and eloidisin) were tested on $105 \mathrm{KCHO}$, but were unable to elicit any calcium response even at concentrations as high as $1 \mu \mathrm{M}$ (not shown). 


$\begin{array}{ll}\text { GRL } & 105 \\ \text { Y1 } & \\ \text { Y2 } & \\ \text { Y4 } & \\ \text { Y5 } & \\ \text { Y6 } & \end{array}$

$\begin{array}{ll}\text { GRL } & 105 \\ \text { Y1 } & \\ \text { Y2 } & \\ \text { Y4 } & \\ \text { Y5 } & \\ \text { Y6 } & \end{array}$

MSVL--LEQD AYDSSSNVTM EDLLATLNGT ENYEAWRSDW TVFAEN--KW M------NS T-LFSQ--VE NHSVHSNFSE KNAQLLAFEN DDCHLPL-AM MGPIGAEADE NQTVEEMKVE QYGPQTTPRG ELVPDPEPEL IDSTKLI-EV MSFYSKQDYN MDLELDEYYN KTLATENNTA ATRNSDFPVW DDYKSSVDDL M--.-- - - EVSL NHPASNTTST KNNNSAFFYF ESCQPPS-PA

\section{TMI}

TMII

QTIVITLYAV VIIFGFFANL - LVVVITRY KOLHTVTNIF ICYLAIADVA IFTLALAYGA VIILGVSGNL - ALIIIILKO KEMRNVTNIL IVNLSFSDL QVVLILAYCS IILLGVIGNS -LVIHVVIKF KSMRTVTNFF IANLAVADLL MVFIVTSYSI ETVVGVLGNL -CLMCVTVRO KEKANVTNLL IANLAFSDFI QYFLIGLYTF VSLLGFMGNL -LILMALMKK RNQKTTVNFL IGNLAFSDIL LLLLCIAYTV VLIVGLFGNL SLIIIIFKKQ RKAQNFTSIL IANLSLSDTI * $\quad$ * ** * ** *

\section{TMIII}

LCVFNLPLQL HYQLSNNWMF GRVLCYVALP TFGVPLFSSS LSILMIAVDR VAIMCLPFTF VYTLMDHWVF GEAMCKLNPF VQCVSITVSI FSLVLIAVER VNTLCLPFTL TYTLMGEWKM GPVLCHLVPY AOGLAVOVST ITLTVIALDR MCLLCQPLTA VYTIMDYWIF GETLCKMSAF IOCMSVTVSI LSLVLVALR VVLFCSPFTL TSVLLDQWMF GKVMCHIMPF LQCVSVLVST LILISIAIVR VCVMCIHFTI IYTLMDHWIF GDTMCRLTSY VQSVSISVSI FSLVFTAVER

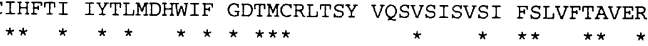

TMIV

YMLIVYPFKK RMTNMQAIIT VVVIIICTVA LSTPLIVYLD YV---EFVHP HQLI INPRGW RPNNRHAYVG IAVIWVLAVA SSLPFLIYOV MTDEPFONVT HRCIVYHLES KISKRISFLI IGLAWGISAL LASPLAIFRE YSLI-EIIPD HQLIINPTGW KPSISQAYLG IVLIWVIACV LSLPFLANSI LENVFHKNHS YHMIKHPISN NLTANHGYFL IATVWTLGFA ICSPLPVFHS LV---ELQET YQLIVNPRGW KPSVTHAYWG ITLIWLFSLL LSIPFFLSYH LTDEPFRNLS

TMRE---QKA YCAEQWPSFL D---KOIYSV SISFLQPVIP VCFDQFPSDS H---RLSYTT LLLVLOYFGP LCFIFICYFK F--.--EIV ACTEKWPGEE KSIYGTVYSL SSLLILYVLP LGIISFSYTR KALEFLADKV VCTESWPLAH H---RTIYTT FLLLFOYCLP LGFILVCYAR FGSALLSSRY LCVESWPSDS Y---RIAFTI SLLLVQYILP LVCLTVSHTS LPTDLYTHQV ACVENWPSKK D---RLLFTT SLFLLQYFVP LGFILICYLK

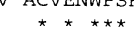
$* * * *$ *

VC.........100 amino acid residues. ........ CF

351

TMVI

ICH-VLRNRP V------KK HDTRRNQRTN RILIAVVLTF TVCWLPWNLF 282 IYI-RLKRRN NMMDKMRDNK YRSSETKRIN IMLLSIVVAF AVCWLPLTIF 286 IWS-KLKNHV SPGAANDHYH QRRQKTTK-- -MLVCVVVVF AVSWLPLHAF 291 IYR-RLQRQG RVFHKGTY-S LRAGHMKQVN VVLVVMVVAF AVLWLPLHVF 288 EIKPEENSDV HELRVKRSVT RIKKRSRSVF YRLTILILVF AVSWMPLHLF IVI-CLRRRN AKVDKKKENE GRLNENKRIN TMLISIVVTF GACWLPRISS 281

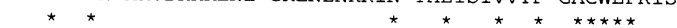

\section{TMVII}

ALTAEFSHVV VKGKYFTFID LMLKVFAMSS ACINPFLYGW LNDRFKKELG NTVFDWNHQI IATCNHNLLF LLCHLTAMIS TCVNPIFYGF LNKNFORDLQ QLAVDIDSQV LDLKEYKLIF TVFHIIAMCS TFANPLLYGW MNSNYRKAFI NSLEDWHHEA IPICHGNLIF LVCHLLAMAS TCVNPFIYGF LNTNFKKEIK HVVTDFNDNL ISNRHFKLVY CICHLLGMMS CCLNPILYGF LNNGIKADLV MSSLTGIMRC

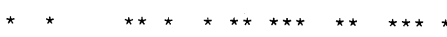

KLFGYRLC DA IHSEVSVTFK AKKNLEVRKN SGPNDSFTEA TNV ALVLTCQQSAP LEESEHLPLS TVHTEVSKGS LRLSGRSNPI SLIHCLHM

40
36

97

8

FIG. 1. Sequence comparison of GRL105 with the amino acid sequences of cloned human NPY-receptors. Gaps introduced to obtain optimal alignment are indicated by dashes. Asterisks mark the positions where at least two of the aligned sequences are identical to GRL105. Bars numbered TMI to TMVII indicate the positions of the transmembrane regions. Sequences are taken from Herzog et al. (1992) (Y1), Lundell et al. (1995) (Y4), Gerald et al. (1995) (Y2), Gerald et al. (1996) (Y5) and Matsumoto et al. (1996) (y6). 


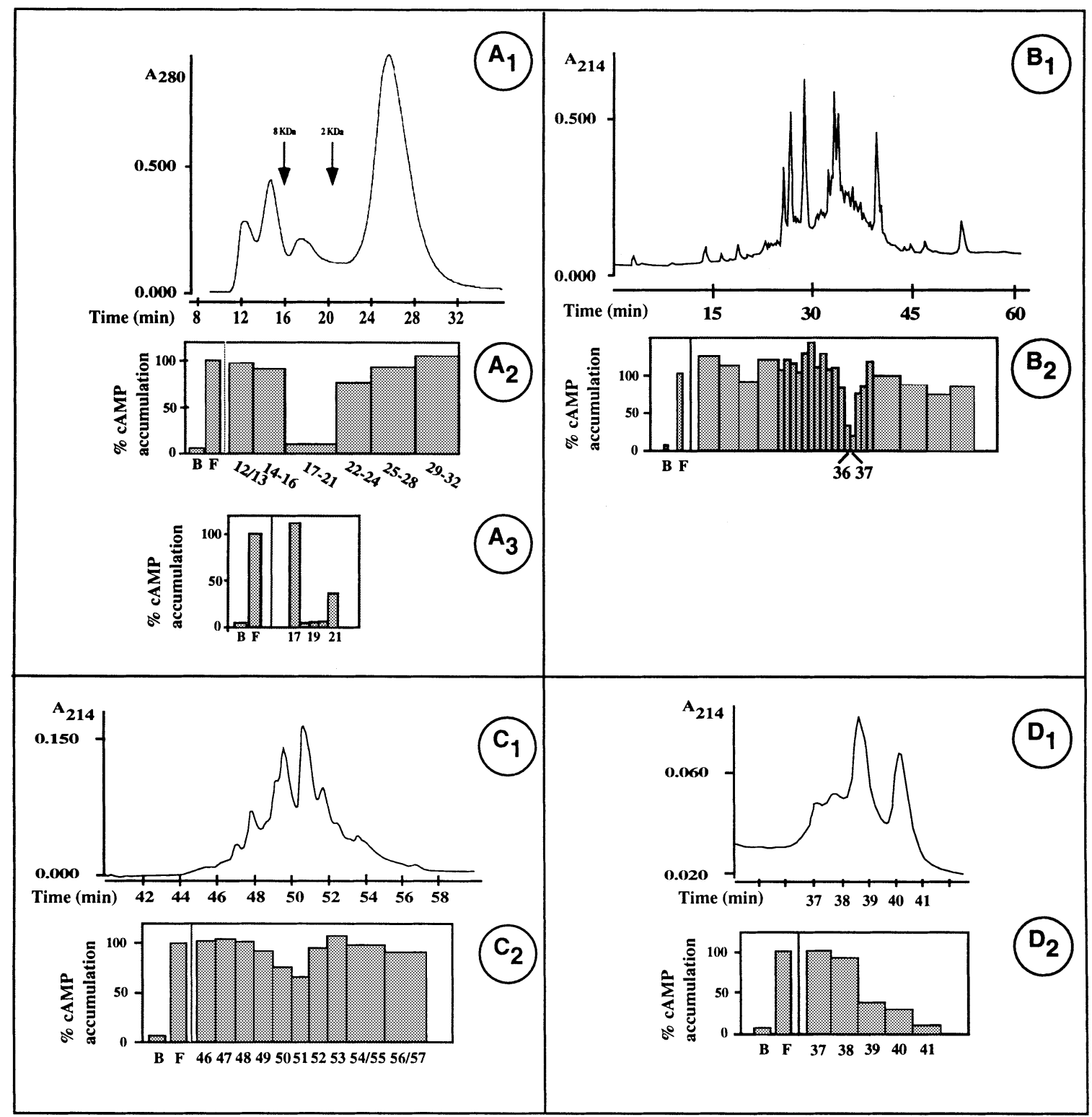

FIG. 2. Purification of the endogenous ligand for GRL105. All assays were performed on a CHO cell line stably transfected with GRL105 cDNA (designated 105KCHO6). The top half of each panel gives the chromatogram for the HPLC purification indicated. (A1) HPGPC fractionation of an extract of 550 Lymnaea brains, (B1) rpHPLC fractionation of the combined fractions 18-20 from (A), (C1) rpHPLC fractionation of the combined fractions 36 and 37 from (B), (D1) rpHPLC fractionation of the combined fractions 50 and 51 from (C). The bottom half of each panel shows the effect of the indicated HPLC fractions on the forskolin-induced cAMP levels in 105KCHO6 cells (average of three determinations). The cAMP level obtained after stimulation by $10 \mu \mathrm{M}$ forskolin was taken as $100 \%$ [ $\mathrm{B}=$ Basal cAMP level, $\mathrm{F}$ = forskolin-stimulated cAMP level (on average 22 pmol cAMP/well)]. cAMP assays as shown in (A2), (A3), (B2), (C2) and (D2) were performed using 2, 2, 4 and $20 \mathrm{CNS}$ equivalents for each determination, respectively.

\section{Discussion}

\section{Isolation of a $c D N A$ encoding a neuropeptide receptor in the brain of Lymnaea stagnalis and identification of the endogenous ligands for this receptor}

We have described a PCR-based cloning of a putative neuropeptide receptor-encoding cDNA from the CNS of Lymnaea stagnalis. Based on a sequence comparison with cloned receptors, the translated amino acid sequence (called GRL105) revealed the highest sequence identity with mammalian neuropeptide Y-receptors. In order to identify the endogenous ligand for this putative Lymnaea homologue of an NPY-receptor, we stably expressed the GRL105 cDNA in CHO cells. These transfected cells were challenged with partially purified
Lymnaea brain extracts, and inhibition of forskolin-stimulated cAMP accumulation was monitored. Finally, bioactive peptides were purified to homogeneity by successive rounds of rpHPLC. Using this approach, we were able to isolate two endogenous ligands for the Lymnaea neuropeptide receptor. Both peptides displayed considerable homology with the family of NPY and NPY-related peptides, and differed only in the N-terminal part. Most likely, one peptide is an N-terminally truncated form of the other, lacking the first four amino acids. We assume that this truncation is due to a specific degradation of the complete peptide, as a result of extraction and purification steps. The truncated form, tested for its potency in reducing forskolin-stimulated cAMP levels in $105 \mathrm{KCHO}$ cells, has only about $10 \%$ of the activity of the full length peptide (not shown). 


$$
\begin{aligned}
& \text { lyNPY } \\
& \text { NPF Moniezia } \\
& \text { NPF Helix } \\
& \text { NPY Aplysia } \\
& \text { NPY Torpedo } \\
& \text { NPY Goldish } \\
& \text { NPY Frog } \\
& \text { NPY Chicken } \\
& \text { NPY Rat } \\
& \text { NPY Human } \\
& \text { PMY Lamprey } \\
& \text { PYY Salmon } \\
& \text { PP Bullfrog } \\
& \text { PP Guinea Pig } \\
& \text { PP Turkey } \\
& \text { PYY Rat } \\
& \text { PP Sheep }
\end{aligned}
$$

\section{P DK D F IVNPS D L V - L DNKA ALRDY LR O INEYFAI IGRPRF-NH2 S T QMLSP PERPREFRHPNELRQYLLE LNEYYA IM/GRTRF-NH2 DN S EMLA P PPRPEEFT S A Q QLR QYLAALNEYYSTMGRPRF-NH2}

\begin{abstract}
Y P SKPDNPGEG A P A E DLA KYY SALR HYI NL I TRQRY-NH2 Y P TKPDNPGEG A P A EELA KYY S ALR HYI NLI TRQRY-NH2 Y PSK PDNPGEDA P A EDM A KYY SALR HYINLI T R RY-NH2 Y P SKPD SPGEDAP AE DMARYY SALR HYINL I TRQRY-NH2

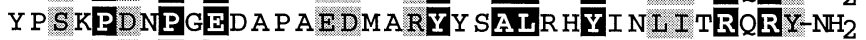
Y P SKRDNPGEDA P A E DMARYY SALR HYI NLI TRQRY-NH2
\end{abstract}

\section{MP P KPDNPS P D A SPEELSKYMLAVRNYI NL I TRQRY-NH2 Y P P K PENPGEDA P PEELA KYY TALR HY I NLITRQRY-NH

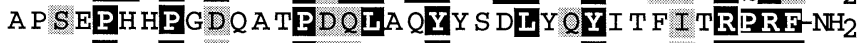 A P L ERVYPGDDA TRQQMA QYAAEMRRYINMLTRPRF-NH2

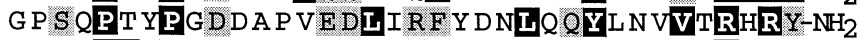

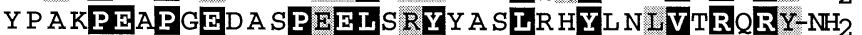 A S L E PEY PGDNA T PEQMA Q YA AEIRR RINM LTRPRY-NH2}

FIG. 3. Amino acid sequence of lyNPY and comparison with related peptide sequences. Amino acids are given by their single-letter codes. The amino acid sequence of lyNPY is given at the top of the figure and is compared with invertebrate NPY and NPF sequences, with vertebrate NPY sequences and vertebrate NPY-related sequences. Residues identical to the corresponding ones in lyNPY are highlighted in reversed contrast, residues that are evolutionary related to lyNPY are shaded grey. The dash in the Monieza NPF sequence was introduced to allow for optimal alignment. Sequences were taken from Larhammar et al. (1993).
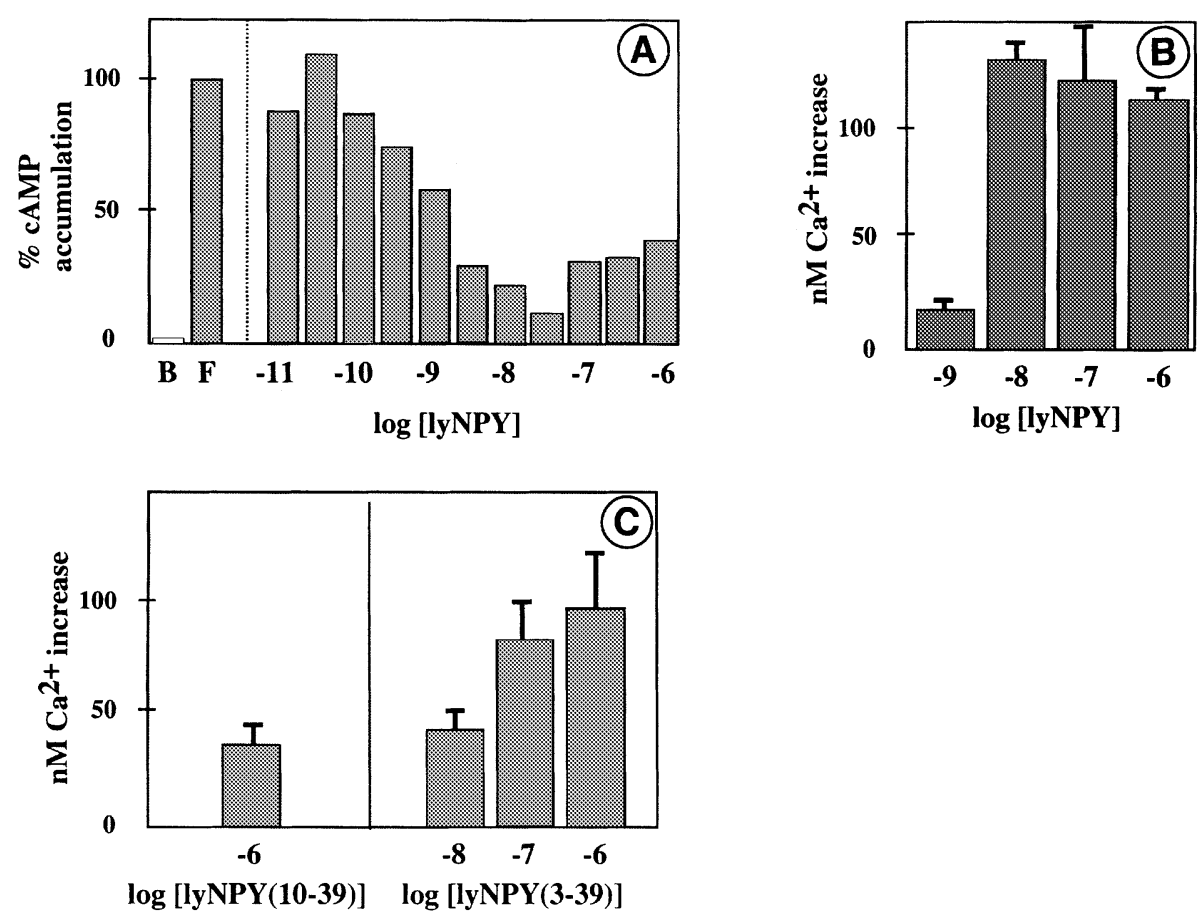

FIG. 4. Dose-effect curves for synthetic lyNPY and lyNPY analogues. All assays were performed in the cell line 105KCHO6. (A) Inhibition of forskolininduced cAMP production by different concentrations of lyNPY. The cAMP level is expressed as a percentage of the level obtained after stimulation by $10 \mu \mathrm{M}$ forskolin (corresponding to $24 \mathrm{pmol} \mathrm{cAMP} / \mathrm{well}$ ). Shown is a representative experiment out of three performed. (B) Effect of various concentrations of lyNPY on the intracellular $\mathrm{Ca}^{2+}$ concentration. The data are given as the increase in $\mathrm{Ca}^{2+}$ concentration and are the mean of three determinations $\pm \mathrm{SD}$. (C) Effect of lyNPY analogues on the intracellular $\mathrm{Ca}^{2+}$ concentration. The data are given as the increase in $\mathrm{Ca}^{2+}$ concentration and are the mean of three determinations $\pm \mathrm{SD}$.

The ligand for neuropeptide receptor GRL105 is a Lymnaea homologue of NPY

In vertebrates, NPY is the most abundant neuropeptide in the brain, and is known to exert a vast number of peripheral and central effects, including the regulation of blood pressure, heart rate, respiration, sexual behaviour, psychomotor activities, food intake and circadian rhythm (Colmers \& Bleakman, 1994; Grundemar \& Håkanson, 1994; Larhammar, 1996a). Vertebrate NPYs (and PPs) are characterized by the presence of two peptide domains and a number of specific amino acids that are important for creating a typical three-dimensional structure of these peptides. The N-terminal part forms a polyproline helix, in which the two prolines at positions 5 and 8 seem essential 
since they have been conserved (see Fig. 3). The proline at position 2 that is found in most vertebrate NPYs and PPs is likely to be of lesser importance since it is lacking in sheep PP (see Fig. 3); a corresponding proline is also absent from all invertebrate NPY-like peptides. The polyproline helix is folded onto an amphipatic helix formed by the carboxy terminal 20 amino acids and interacts directly with three residues at positions 20, 24 and 27 in this carboxy-terminal region (Glover et al., 1983; Glover et al., 1985; Allen et al., 1987). The five residues mentioned above, which are essential for the threedimensional structure, are conserved between lyNPY, Torpedo NPY, Goldfish NPY and human NPY, suggesting that lyNPY can adopt a similar tertiary structure. A further comparison of lyNPY, other invertebrate NPY homologues, and vertebrate NPYs and PPYs (Fig. 3) shows that in particular the last four residues, including the carboxyterminal amidation, have been strongly conserved during evolution. Interestingly, this region has been shown to be essential for the biological activity of vertebrate NPYs (Lundberg et al., 1990).

\section{The Lymnaea neuropeptide receptor GRL105 is a molluscan homologue of an NPY-like-receptor}

In humans, NPY acts on at least six different receptor subtypes (i.e. Y1, Y2, Y3, Y4, Y5 and a peripheral Y2-like subtype; Blomqvist \& Herzog, 1997) of which the Y1, Y2, Y4 and Y5 receptors (Lundell et al., 1995; Herzog et al., 1992; Larhammar et al., 1992; Gerald et al., 1995; Rose et al., 1995; Gerald et al., 1996) have been cloned. The Y1 and Y2 receptors were originally distinguished on the basis of their ability to bind specific NPY subfragments fragments: Y1 binds only the complete NPY, while Y2 also binds carboxy terminal fragments. Recently, N-terminally truncated forms of NPY were also shown to be able to inhibit forskolin-induced cAMP accumulation in HEK 293 cells (Gerald et al., 1995) and $\mathrm{Ca}^{2+}$ mobilization in $\mathrm{CHO}$ cells (Rose et al., 1995) transfected with the human Y2 receptor. The pharmacological profile of the Y5 receptor most resembles that of the $\mathrm{Y} 1$ receptor. However, the Y5 receptor can be fully activated with porcine NPY (3-36) and human PYY (3-36), analogues exerting low or no activity on cloned $\mathrm{Y} 1$ receptors. In addition, the Y5 receptor differs from all other NPY-receptors as it exhibits an extremely long intracellular loop between TMV and VI, and has a short C-terminal region.

We propose that GRL105 should be classified as a molluskan homologue of an NPY-like receptor based on the following: (i) the endogenous ligand for GRL105 is a Lymnaea counterpart of NPY; (ii) the amino acid sequence of GRL105 is most closely related to the sequence of mammalian NPY-receptors; and (iii) the signal transduction pathways and threshold concentration for activation of GRL105 expressed in CHO cells are similar to those of heterologously expressed mammalian NPY-receptors. A further classification of GRL105 as belonging to a particular subtype on the basis of its amino acid sequence seems inept, as GRL105 shares almost equal sequence identity to all NPY-receptor subtypes. The observation that $\mathrm{N}$-terminally truncated forms of lyNPY have impaired or no biological activity, however, indicates that the Lymnaea receptor is not a Y2 subtype.

The physiological role for NPY-like peptides in invertebrate species is largely unknown, although they have been implicated in the regulation of motor functions during egg laying in the seaslug, Aplysia californica (Rajpara et al., 1992). In addition, a receptor has been cloned from the fruitfly Drosophila melanogaster (Li et al., 1992) exhibiting an $\mathrm{EC}_{50}$ of $0.3 \mu \mathrm{M}$ for human PYY. However, the sequence identity of this supposed Drosophila NPY receptor to mammalian NPY receptors is no greater than to other mammalian GPCRs
(Larhammar, 1996b). Also, an endogenous ligand for this fruitfly receptor has never been identified. In Lymnaea, the isolation of lyNPY and the cloning of a cDNA encoding its cognate receptor will now permit for the first time the detailed mapping of those cells that produce the ligand and those neurons that express the receptor. In addition, the advantages of the Lymnaea CNS as a model system, i.e. the ability to map individual neurons and determine their function in relation to control of physiological processes, as well as the possibility to reconstitute functional neuronal networks from individual neurons in vitro (Syed et al., 1990), will now enable us to unravel the role of NPY and its cognate receptor in neuronal communication.

\section{Acknowledgements}

This research was supported by a grant from the European Community (89300257/JU1). We thank Mrs C. van der Vliet and Dr M. J. Smit for technical help and advice. The nucleotide sequence reported in this paper has been deposited in the EMBL, GenBank databases (accession number X82088).

\section{Abbreviations}

$\begin{array}{ll}\text { CNS } & \text { central nervous system } \\ \text { G protein } & \text { guanine, nucleotide binding regulatory protein } \\ \text { GPCR } & \text { G-protein-coupled receptor } \\ \text { HPGPC } & \text { high-performance gel permeation chromatography } \\ \text { NPY } & \text { neuropeptide Y } \\ \text { PP } & \text { pancreatic polypeptide } \\ \text { PYY } & \text { peptide YY } \\ \text { rpHPLC } & \text { reverse phase high-pressure liquid chromatography } \\ \text { TFA } & \text { trifluoroacetic acid }\end{array}$

\section{References}

Allen, J.M., Novotny, J., Martin, J. \& Heinrich, G. (1987) Molecular structure of mammalian neuropeptide Y: analysis by molecular cloning and computer aided comparison with crystal structure of avian homologue. Proc. Natl. Acad. Sci. USA, 84, 2532-2536.

Bard, J.A., Walker, M.W., Branchek, T.A. \& Weinshank, R.L. (1995) Cloning and functional expression of a human Y4 subtype receptor for pancreatic polypeptide, neuropeptide Y, and peptide YY. J. Biol. Chem., 270, $26762-26765$.

Blomqvist, A.G. \& Herzog, H. (1997) Y-receptor subtypes - how many more? Trends Neurosci., 7, 294-298.

Bradbury, A.F. \& Smyth, D.G. (1991) Peptide amidation. Trends Biochem. Sci., 16, 112-115.

Colmers, W.F. \& Bleakman, D. (1994) Effects of neuropeptide Y on the electrical properties of neurons. Trends Neurosci., 17, 373-379.

Cox, K.J., Tensen, C.P., van der Schors, R., Li, K.W., van Heerikhuizen, H., Vreugdenhil, E., Geraerts, W.P.M. \& Burke, J.F. (1997) Cloning, characterization and expression of a G-protein-coupled receptor from Lymnaea stagnalis and identification of a leucokinin-like peptide, PSFHSWSamide as its endogenous ligand. J. Neuroscience, 17, 1197-1205.

Gehlert, D.R., Beavers, L.S., Johnson, D., Gackenheimer, S.L., Schober, D.A. \& Gadski, R.A. (1996) Expression cloning of a human brain neuropeptide Y Y2 receptor. Mol. Pharmacol., 49, 224-228.

Geraerts, W.P.M., Smit, A.B.K.W.L., Vreugdenhil, E. \& van Heerikhuizen, H. (1991) Neuropeptide gene families that control reproductive behaviour and growth in molluscs. In Osborne, N.N. (ed.), Current Aspects of the Neurosciences. Vol. 3, pp. 255-304.

Gerald, C., Walker, M.W., Criscione, L., Gustafson, E.L., Batzl-Hartmann, C., Smith, K.E., Vaysse, P., Durkin, M.M., Laz, T.M., Linemeyer, D.L., Schaffhauser, A.O., Whitebread, S., Hofbauer, K.G., Taber, R.I., Branchek, T.A. \& Weinshank, R.L. (1996) A receptor subtype involved in neuropeptide-Y-induced food intake. Nature, 382, 168-171.

Gerald, C., Walker, M.W., Vaysse, J.-J., He, C., Branchek, T.A. \& Weinshank, R.L. (1995) Expression cloning and pharmacological characterization of a human hippocampal neuropeptide Y/peptide YY Y2 receptor subtype. J. Biol. Chem., 270, $26758-26761$.

Glover, I.D., Barlow, D.J., Pitts, J.E., Wood, S.P., Tickle, I.J., Blundell, T.L., Tatemoto, K., Kimmel, J.R., Wollmer, A., Strassburger, W. \& Zhang, Y.-S. 
(1985) Conformational studies on the pancreatic polypeptide hormone family. Eur. J. Biochem., 142, 379-385.

Glover, I., Illyas, H., Pitts, J., Wood, S.D.M., Tickle, I. \& Blundell, T. (1983) Conformational flexibility in a small globular hormone: X-ray analysis of avian pancreatic polypeptide at 0.98 -A resolution. Biopolymers, 22, 293-302.

Gregor, P., Feng, Y., DeCarr, L.B., Cornfield, L.J. \& McCaleb, M.L. (1996) Molecular characterization of a second mouse pancreatic polypeptide receptor and its inactivated human homologue. J. Biol. Chem., 271, 27 776-27 781.

Grundemar, L. \& Håkanson, R. (1994) Neuropeptide Y effector systems: perspectives for drug development. Trends Pharmacol. Sci., 15, 153-159.

Grynkiewicz, G., Poenie, M. \& Tsien, R.Y. (1985) A new generation of $\mathrm{Ca}^{2+}$ indicators with greatly improved fluorescence properties. J. Biol. Chem., 260, 3440-3450.

Herzog, H., Hort, Y.J., Ball, H.J., Hayes, G., Shine, J. \& Selbie, L.A. (1992) Cloned human neuropeptide $\mathrm{Y}$ receptor couples to two different second messenger systems. Proc. Natl. Acad. Sci. USA, 89, 5794-5798.

Knol, J.C., van der Slik, A.R., van Kesteren, E.R., Planta, R.J., van Heerikhuizen, H. \& Vreugdenhil, E. (1995a) A novel G protein alpha subunit containing atypical guanine nucleotide-binding domains is differentially expressed in a molluscan nervous system. J. Biol. Chem., 270, 18 804-18 808

Knol, J.C., Ramnatsingh, S., van Kesteren, E.R., van Minnen, J., Planta, R.J., van Heerikhuizen, H. \& Vreugdenhil, E. (1995b) Cloning of a molluscan G-protein alpha subunit of the Gq class which is expressed differentially in identified neurons. Eur. J. Biochem., 230, 193-199.

Knol, J.C., van Kesteren, E., Planta, R.J., Vreugdenhil, E. \& van Heerikhuizen, H. (1994) A G protein beta subunit that is expressed in the central nervous system of the mollusc Lymnaea stagnalis identified through cDNA cloning. Biochim. Biophys. Acta, 1222, 129-133.

Knol, J.C., Weidemann, W., Planta, R.J., Vreugdenhil, E. \& van Heerikhuizen, H. (1992) Molecular cloning of $G$ protein a subunits from the central nervous system of the pond snail Lymnaea stagnalis. FEBS Lett., 314, 215-219.

Kozak, M. (1987) Compilation and analysis of sequences upstream from the translational start site in eukaryotic mRNAs. Nucl. Acids Res., 12, 857-872.

Krause, J., Eva, C., Seeburg, P.H. \& Sprengel, R. (1992) Neuropeptide Y1 subtype pharmacology of a recombinantly expressed neuropeptide receptor. Mol. Pharmacol., 41, 817-821.

Larhammar, D. (1996a) Evolution of neuropeptide Y, peptide YY and pancreatic polypeptide. Reg. Pept., 62, 1-11.

Larhammar, D. (1996b) Structural diversity of receptors for neuropeptide Y, peptide YY and pancreatic polypeptide. Reg. Pept., 65, 165-174.

Larhammar, D., Blomqvist, A.G. \& Soderberg, C. (1993) Evolution of neuropeptide Y and its related peptides. Comp. Biochem. Physiol. C, 106, 743-752.

Larhammar, D., Blomqvist, A.G., Yee, F., Jazin, E., Yoo, H. \& Wahlested, C. (1992) Cloning and functional expression of a human neuropeptide Y/peptide YY receptor of the Y1 type. J. Biol. Chem., 267, $10935-10938$.

Leurs, R., Smit, M.J., Menge, W.M.B.P. \& Timmermans, H. (1994) Pharmacological characterization of the human histamine $\mathrm{H} 2$ receptor stably expressed in Chinese hamster ovary cells. Br. J. Pharmacol., 112, 847-854.

Li, X.J., Wu, Y.-N., North, R.A. \& Forte, M. (1992) Cloning, functional expression and developmental regulation of a neuropeptide $\mathrm{Y}$ receptor from Drosophila melanogaster. J. Biol. Chem., 267, 9-12.

Libert, F., Parmentier, M., Lefort, A., Dinsart, D., Sande, S.J.V., Maenhaut, C., Simons, M.J., Dumont, J.E. \& Vassart, G. (1989) Selective amplification of four new members of the $\mathrm{G}$ protein-coupled receptor family. Science, 244, 569-572.

Lundberg, J.M., Franco-Cereceda, A., Hemsen, A., Lacroix, J.S. \& Pernow, J. (1990) Pharmacology of noradrenaline and neuropeptide tyrosine (NPY)mediated symphatic cotransmission. Fundam. Clin. Pharmacol., 4, 373-391.

Lundell, I., Blomqvist, A.G., Berglund, M.M., Schober, D.A., Johnson, D., Statnick, M.A., Gadski, R.A., Gehlert, D.R. \& Larhammar, D. (1995) Cloning of a human receptor of the NPY receptor family with high affinity for pancreatic polypeptide and peptide YY. J. Biol. Chem., 270, 29 123-29 128

Matsumoto, M., Nomura, T., Momose, K., Ikeda, Y., Kondou, Y., Akiho, H., Togami, J., Kimura, Y., Okada, M. \& Yamaguchi, T. (1996) Inactivation of a novel neuropeptide Y/peptide YY receptor gene in primate species. $J$. Biol. Chem., 271, 27 217-27 220.

Pearson, W.R. \& Lipman, D.J. (1988) Improved tools for biological sequence analysis. Proc. Natl. Acad. Sci. USA, 85, 2444-2448.

Probst, W.C., Lenore, A.S., Schuster, D.I., Brosius, J. \& Sealfon, S.C. (1992) Sequence alignment of the G-protein coupled receptor superfamily. DNA Cell Biol., 11, 1-20.

Rajpara, S.M., Garcia, P.D., Roberts, R., Eliassen, J.C., Owens, D.F., Maltby, D., Myers, R.M. \& Mayeri, E. (1992) Identification and molecular cloning of a neuropeptide $\mathrm{Y}$ homolog that produces prolonged inhibition in Aplysia neurons. Neuron, 9, 505-513.

Rose, P.M., Fernandes, P., Lynch, J.S., Frazier, S.T., Fisher, S.M., Kodukula, K., Kienzle, B. \& Seethala, R. (1995) Cloning and functional expression of a cDNA encoding a human type 2 neuropeptide Y receptor. J. Biol. Chem., 270, 22 661-22 664.

Sambrook, J., Fritsch, E.F. \& Maniatis, T. (1989) Molecular Cloning: A Laboratory Manual, 2nd edn. Cold Spring Harbor Laboratory, Cold Spring Harbor, NY.

Sanger, F., Nicklen, S. \& Coulson, A.R. (1977) DNA sequencing with chainterminating inhibitors. Proc. Natl. Acad. Sci. USA, 74, 5463-5467.

Syed, N.I., Bulloch, A.G.M. \& Lukowiak, K. (1990) In vitro reconstruction of the respiratory central pattern generator of the mollusk Lymnaea stagnalis. Science, 250, 282-285.

Tensen, C.P., van Kesteren, E.R., Planta, R.J., Cox, K., Burke, J.F., van Heerikhuizen, H. \& Vreugdenhil, E. (1994) A G-protein-coupled receptor with LDL-binding motifs suggests a role for lipoprotein in G-linked signal transduction. Proc. Natl. Acad. Sci. USA, 91, 4816-4820. 